Journal of Applied Pharmaceutical Science Vol. 6 (04), pp. 093-097, April, 2016

Available online at http://www.japsonline.com

DOI: $10.7324 / \mathrm{JAPS} .2016 .60413$

ISSN 2231-3354 (cc) EY-NC-SA

\title{
Vegetative growth, chemical composition, and flavonoids content of Azadirachta indica plants as affected by application of yeast natural extract
}

\author{
Lobna S. Taha*, Soad M.M. Ibrahim, Nahed G. Abdel Aziz \\ Department of Ornamental plants and Woody Trees.National Research Centre, Dokki, Egypt.
}

\begin{tabular}{|c|c|}
\hline ARTICLE INFO & ABSTRACT \\
\hline $\begin{array}{l}\text { Article history: } \\
\text { Received on: } 06 / 02 / 2016 \\
\text { Revised on: } 07 / 03 / 2016 \\
\text { Accepted on: } 30 / 03 / 2016 \\
\text { Available online: } 30 / 04 / 2016\end{array}$ & $\begin{array}{l}\text { This experiment was carried out during } 2013 \text { and } 2104 \text { seasons on Azadirachta indica plants at National } \\
\text { Research Centre greenhouse, Egypt. Experiment studied the effect of foliar spraying plants with dry yeast } \\
\text { (Saccharomyces cerevisiae) extract at various concentrations }(0,5,10,15 \text { and } 20 \%) \text { on growth, pigments, NPK } \\
(\%) \text {, total soluble sugars, indoles, phenols and flavonoids leaves contents. Results showed that spraying neem } \\
\text { plants with yeast extract at } 15 \% \text { significantly increased growth parameters (plants height, stem and root fresh }\end{array}$ \\
\hline $\begin{array}{l}\text { Key words: } \\
\text { Saccharomyces cerevisiae, } \\
\text { yeast, Neem plants, } \\
\text { pigments, mineral, Phenolic } \\
\text { content. }\end{array}$ & $\begin{array}{l}\text { and dry weights) and enhanced total chlorophylla, phosphorus, potassium and total soluble sugars content. } \\
\text { Using the concentration } 5 \% \text { of dry yeast extract gave the highest values of chlorophyll b, total carotenoids and } \\
\text { total chlorophyll content. Nitrogen content was produced at the highest value }(3.55 \%) \text { in plants treated with dry } \\
\text { yeast extract at } 10 \% \text {. The foliar application of yeast extract at } 10,15 \text { and } 20 \% \text { resulted the highest values of total } \\
\text { soluble phenols }(72.48,72.27 \text { and } 73.46 \mathrm{mg} / \mathrm{g} \text { D.W., respectively). The highest flavonoids leave content }(3.23 \\
\text { and } 3.14 \mathrm{mg} \mathrm{CE/g} \mathrm{D.W.)} \mathrm{were} \mathrm{obtained} \mathrm{when} \mathrm{the} \mathrm{dry} \mathrm{yeast} \mathrm{extract} \mathrm{was} \mathrm{used} \mathrm{at} 15 \text { and } 20 \% \text {, respectively. On the } \\
\text { other hand, all treatments had no significant effect on stem diameter, number of leaves /plant and root length. }\end{array}$ \\
\hline
\end{tabular}

\section{INTRODUCTION}

Neem (Azadirachta indica A. Juss.), a member of the family Meliaceae, is an evergreen, tropical forest tree. It can grow on poor soils and wastelands and is famous for its drought resistance (Radwanski, 1977). This tree is a multipurpose timber tree and possess high value products that are extracted for use as insecticides, fertilizers and multipurpose medicines. Its chemical constituents have several biological activities, such as immunestimulation, blood purification, anti- inflammation, anti-tumor, insect repulsion and bactericidal activity. All parts of these plants including fruit, seed, leaf, root and bark are used for their medicinal properties. It contains more than 100 bioactive compounds. The main active compounds are highly oxidized triterpenoids called limonoids. Azadirachtin is the most important

\footnotetext{
* Corresponding Author

Lobna S. Taha, Department of Ornamental plants and Woody Trees -National Research Center, Dokki, Egypt.

Email:lobnasalah82@yahoo.com
}

important bioactive compound, it exists in all parts of the neem tree, but is concentrated in the seed kernel. Others are gedunin, nimbin and sodium nimbinate (Premananda, 2011). Biostimulants are an organic materials that have been shown to influence several metabolic processes such as respiration, photosynthesis, nucleic acid synthesis and ion uptake and when applied in small quantities, enhances plant growth and development. Active dry yeast is considered as biostimulant, natural source of cytokinins that stimulates cell division and enlargement as well as the synthesis of protein, nucleic acid and chlorophyll formation (El- Desouky et al., 1998; Wanas 2002 and Wanas, 2006). Moreover, it contains cryoprotective agent, i.e. sugars, proteins, amino acids and also several vitamins (Mahmoued, 2001). It may enhance water holding capacity, increase antioxidants, and enhance metabolism (Abbas, 2013). Bread yeast (Saccharomyces cerevisiae) is usually added to soil or as foliar application to crops (EL-Ghamriny et al., 1999)due to its content of many nutrient elements as well as its role in producing important substances like growth regulators such as gibberellins, auxins (Sarhan and Sharif, 1988) and its ability to 
produce a group of enzymes (Dinkha and Al-Khazragji, 1990). The goal of the present work was to evaluate the effects of these dry yeast natural extract as a biostimulant on plant growth, photosynthetic pigments and chemical composition of Azadirachta indica plants.

\section{MATERIALS AND METHODS}

The experiment was carried out during two successive seasons (2013 and 2014) at the greenhouse of the National Research Centre, Dokki, Egypt to study the effect of various dry yeast extract concentrations on growth, NPK (Total nitrogen, phosphorus and potassium), photosynthetic pigments, total soluble sugars, indoles, phenols and flavonoid leaves content of Azadirachta indica plants (two years old).

Neem plants $20-22 \mathrm{~cm}$ with $10-14$ leaves were obtained in May, 2014 in earthenware that were filled with media containing a mixture of sand and peat as 1:1 by volume. The plants were fertilized with $20 \mathrm{~g} /$ pot kristalon in four doses after 4, 8, 16 and 20 weeks from transplanting, after 50 days plants were transolocated to the pots $(50 \mathrm{~cm}$ width) contained $8 \mathrm{Kg}$ mixture of sand and peat as 1:1 by volume. The first spraying treatment of various dry yeast concentration in August, 2014 and the second after two months and were repeated in the two season.

\section{Chemicals}

The chemicals used in this study including the solvents were of analytical grade and used without testing and purification.

\section{Extraction and determination Yeast extract preparation}

Saccharomyces cerevisiae newly produced active dry yeast was obtained (SIL-41, Zone Potuaire 59211 SANTESFrance) and various concentrations $(0,5,10,15$ and $20 \mathrm{~g})$ of yeast were weighed and put with $25 \mathrm{~cm}^{3}$ of water in a glass beakers with teaspoon full of sugar beaker. The beakers of each concentration were kept in a dark warm place for 30 minutes as described by Hanafy et al. (2012). Contents of the beakers were then filtered into a measuring flasks and water was added to $100 \mathrm{~cm}$ final volume for each one.

\section{Data Recorded}

\section{Vegetative growth}

The design of the experiment was complete randomized blocks in 3 replicates (each replicate contained 5 plants). Plants were randomly chosen at 80 days after treatment in both seasons to estimate plant height $(\mathrm{cm})$, stem diameter $(\mathrm{cm})$, number of leaves/ plant, stem fresh and dry weights $(\mathrm{g}) /$ plant, root length $(\mathrm{cm})$, root fresh and dry weights (g)/plant.

\section{Photosynthetic pigments}

Chlorophyll, a, b and carotenoids concentrations were determined as $\mathrm{mg} / \mathrm{100 \textrm {g }}$ fresh weight, in leaves of Azadirachta indica using the method described by Saric et al. (1967).

\section{NPK estimation}

Samples of leaves were taken to determine total nitrogen (Horneck and Miller, 1998), phosphorus (Sandell, 1950) and potassium (Horneck and Hanson, 1998).

\section{Total Soluble Sugars}

It determined in the methanolic extract by using the phenol-sulfuric method according to Dubois et al. (1966).

\section{Total indoles and phenols}

The total indoles were determined by using "Erlic's reagent" according to Larsen et al. (1962). While, total soluble phenols were calorimetrically determined using Folin Ciocaltea reagent (A.O.A.C. 1985).

\section{Total flavonoid}

Total flavonoid was determined according tocolorimetric method by Adom et al. (2005), each volumetric flask were reacted with $5 \%$ sodium nitrite $(200 \mu \mathrm{L})$. After $6 \mathrm{~min}, 10 \% \mathrm{AlCl}_{3}(0.3 \mathrm{ml})$ was added and at another $6 \mathrm{~min} .1 \mathrm{M} \mathrm{NaOH}(2 \mathrm{ml})$ was added, followed by adjusting the volume to $5 \mathrm{~mL}$ with deionized water and mixed well. Absorbance of the reaction mixture was read at $510 \mathrm{~nm}$. Total flavonoid contents of each sample (three replicates per treatment) were expressed as mg catechin equivalents per gram of dry weight ( $\mathrm{mg} \mathrm{CE} \mathrm{g}^{-1} \mathrm{DW}$ ) through the calibration curve with catechin.

\section{Statistical analysis}

The data obtained were statistically analyzed by using the least significant differences test (L.S.D) at $0.05 \%$ according to Snedecor and Cochran (1980). The results were presented as mean values $\pm \mathrm{SD}$ (standard deviations).

\section{RESULTS AND DISCUSSION}

\section{Growth characteristics}

Vegetative growth parameters of Azadirachta indica (plants height, stem and root fresh and dry weights)significantly influenced by all foliar application with yeast extract at 5,10, 15 and $20 \%$ as shown in Table (1).Maximum stimulatory effect on plant height $(\mathrm{cm})$, stem fresh and dry weight $(\mathrm{g})$ and root fresh and dry weights $(\mathrm{g})$ was observed in plants treated with $15 \%$ yeast extract which produced $(134.67 \mathrm{~cm}, 72.12,21.78,42.80$ and 9.16 g, respectively) as compared with control plant which gave (97 $\mathrm{cm}, 38.76,15.42,17.7$ and $5.96 \mathrm{~g}$, respectively).However, all treatments had no significant effect on stem diameter, number of leaves /plant and root length. The enhancement effect of yeast extract might be attributed to its influence on metabolism, biological activity and photosynthetic pigments and enzyme activity which in turn encourage vegetative growth (Wanas, 2002 and El-Sherbeny et al., 2007). It is acting as a source of plant growth hormones, carbohydrates, amino acids and vitamins. 
Table 1: Effect of dry yeast extract concentrations on vegetative growth characters of Azadirachta indica (as mean of the two seasons).

\begin{tabular}{|c|c|c|c|c|c|c|c|c|}
\hline Treatment & $\begin{array}{l}\text { Plant height } \\
(\mathbf{c m})\end{array}$ & $\begin{array}{c}\text { Stem diameter } \\
(\mathrm{cm})\end{array}$ & $\begin{array}{c}\text { number of } \\
\text { leaves /plant }\end{array}$ & $\begin{array}{l}\text { Stem } \\
\text { F.W. } \\
\text { (g) }\end{array}$ & $\begin{array}{c}\text { Stem D.W. } \\
\text { (g) }\end{array}$ & $\begin{array}{l}\text { Root length } \\
(\mathrm{cm})\end{array}$ & $\begin{array}{c}\text { Root F.W. } \\
\text { (g) }\end{array}$ & $\begin{array}{c}\text { Root D.W. } \\
\text { (g) }\end{array}$ \\
\hline Control $(0 \%)$ & 97 & 0.45 & 37.66 & 38.76 & 15.42 & 30 & 17.7 & 5.96 \\
\hline Yeast 5\% & 108 & 0.55 & 41.66 & 44.55 & 16.69 & 39 & 18.39 & 5.99 \\
\hline Yeast $10 \%$ & 127.67 & 0.46 & 36.67 & 55.81 & 15.23 & 31.66 & 18.85 & 5.91 \\
\hline Yeast $15 \%$ & 134.67 & 0.59 & 48 & 72.12 & 21.78 & 41.67 & 24.80 & 9.16 \\
\hline Yeast $20 \%$ & 108.33 & 0.55 & 30.67 & 39.94 & 10.24 & 37.33 & 12.96 & 4.30 \\
\hline LSD at $5 \%$ & 22.10 & N.S. & N.S. & 18.85 & 4.16 & N.S. & 4.82 & 1.65 \\
\hline
\end{tabular}

Table 2: Effect of dry yeast extract concentrations on photosynthetic pigments (mg/100gF.W.) of Azadirachta indica leaves.

\begin{tabular}{|c|c|c|c|c|c|c|}
\hline Treatment & Chl.a & Chl.b & Total carotenoides & Total chlorophyll & $\operatorname{chl} . a: c h l . b$ & $\begin{array}{l}\text { chl } . a+c h l . b: \\
\text { carotenoids }\end{array}$ \\
\hline Control $(0 \%)$ & 264.45 & 92.6 & 186.09 & 357.05 & 2.86 & 1.92 \\
\hline Yeast $5 \%$ & 450.54 & 226.82 & 366.38 & 677.36 & 1.99 & 1.85 \\
\hline Yeast10\% & 367.07 & 115.43 & 226.48 & 482.5 & 3.18 & 2.13 \\
\hline Yeast $15 \%$ & 469.73 & 188.88 & 290.81 & 658.61 & 2.49 & 2.26 \\
\hline Yeast $20 \%$ & 397.29 & 133.91 & 240.05 & 531.19 & 2.97 & 2.21 \\
\hline LSD at $5 \%$ & 0.005 & 3.32 & 3.04 & 3.32 & - & - \\
\hline
\end{tabular}

Table 3: Effect of dry yeast extract concentrations on NPK (\%) of Azadirachta indica plants.

\begin{tabular}{|c|c|c|c|}
\hline Treatment & $\begin{array}{c}\text { Nitrogen } \\
(\%)\end{array}$ & $\begin{array}{c}\text { Phosphorus } \\
(\%)\end{array}$ & $\begin{array}{c}\text { Potassium } \\
(\%)\end{array}$ \\
\hline Control $(0 \%)$ & $1.51 \pm 0.14$ & $0.021 \pm 0.002$ & $1.03 \pm 0.025$ \\
\hline Yeast $5 \%$ & $3.43 \pm 0.15$ & $0.111 \pm 0.004$ & $1.04 \pm 0.03$ \\
\hline Yeast $10 \%$ & $3.55 \pm 0.11$ & $0.261 \pm 0.020$ & $1.29 \pm 0.05$ \\
\hline Yeast $15 \%$ & $1.66 \pm 0.06$ & $0.323 \pm 0.012$ & $1.49 \pm 0.05$ \\
\hline Yeast $20 \%$ & $0.48 \pm 0.03$ & $0.143 \pm 0.003$ & $0.78 \pm 0.03$ \\
\hline LSD at $5 \%$ & 0.18 & 0.014 & 0.069 \\
\hline
\end{tabular}

Table 4: Effect of dry yeast extract concentrations on total soluble sugars, indoles, phenols and flavonoids content of Azadirachta indica plants.

\begin{tabular}{|c|c|c|c|c|}
\hline Treatment & $\begin{array}{c}\text { Total soluble sugars } \\
(\mathrm{Mg} / 100 \mathrm{gF} . W .)\end{array}$ & $\begin{array}{c}\text { Total indoles } \\
\text { (Mg/100gF.W.) }\end{array}$ & $\begin{array}{l}\text { Total phenols } \\
\text { (Mg/g D.W.) }\end{array}$ & $\begin{array}{l}\text { Total flavonoides } \\
\text { (Mg CE /g D.W.) } \\
\end{array}$ \\
\hline Control $(0 \%)$ & $28.35 \pm 1.36$ & $41.45 \pm 0.60$ & $55.06 \pm 1.96$ & $2.03 \pm 0.22$ \\
\hline Yeast $5 \%$ & $30.62 \pm 1.53$ & $51.46 \pm 0.87$ & $56.39 \pm 1.84$ & $2.42 \pm 0.21$ \\
\hline Yeast $10 \%$ & $32.31 \pm 1.17$ & $51.89 \pm 1.56$ & $72.48 \pm 1.97$ & $2.45 \pm 0.04$ \\
\hline Yeast $15 \%$ & $42.95 \pm 1.28$ & $60.18 \pm 1.03$ & $72.27 \pm 1.98$ & $3.23 \pm 0.24$ \\
\hline Yeast $20 \%$ & $41.09 \pm 1.25$ & $41.17 \pm 0.57$ & $73.46 \pm 1.39$ & $3.14 \pm 0.20$ \\
\hline LSD at $5 \%$ & 2.49 & 1.90 & 3.72 & 0.14 \\
\hline
\end{tabular}

\section{Photosynthetic pigments}

Data presented in Table (2) indicated that addition of different concentrations of dry yeast extract significantly increased pigment concentrations in leaves of Azadirachta indica. Applying yeast extract at $15 \%$ to plants increased contents of chlorophyll a to the highest value $(469.73 \mathrm{mg} / 100 \mathrm{~g}$ F.W.). Whereas, using the concentration $5 \%$ of yeast extract gave the highest values of chlorophyll b, total carotenoids and total chlorophyll (226.82, 366.38 and $677.36 \mathrm{mg} / 100 \mathrm{~g}$ F.W., respectively) comparing with control. Similar results were found when yeast was applied to field bean plants and increased contents of chlorophyll a, b, and total chlorophyll (Homme et al., 1992).

Enhancing the leaf chlorophyll might be attributed to the important role of dry yeast extract as biostimulant action on increasing the availability of water and minerals (Mady, 2009). Moreover, the improvement of photosynthetic pigments in response to the foliar application of active dry yeast may be attributed to bioregulators which affect the balance between photosynthesis and photorespiration in plants (Olaiya, 2010; Abou El-Yazied and Mady, 2011)

\section{Mineral content}

Data in Table (3) illustrated that yeast extract increased NPK (\%)content of Neem plants. Nitrogen content was at the highest value $(3.55 \%)$ in plants treated with foliar application at $10 \%$ of yeast extract, while the concentration $15 \%$ was favored treatment for increasing phosphorus and Potassium plant content ( 0.323 and $1.49 \%$, respectively) as compared with control plants. Increasing the content of leaves nutrient elements may be due to the positive effective of yeast extract on increasing vegetative growth as a result of dry yeast content in many nutrient minerals and its compounds like growth regulators (Sarhan and Sharif, 1988). Homme et al. (1992) mentioned that yeast also facilitate the growth of plants by improving the uptake of nutrients and production of some phytohormones and convert insoluble form of phosphorous into soluble one, enhancing phosphorous availability to plants.

Total soluble sugars, indoles, phenols and flavonoids content

As shown in Table (4), most of dry yeast extract treatments caused significant increase in total soluble sugars, 
indoles, phenols and flavonoids leaves contents as compared with control plants. The best results were obtained from total soluble sugars (42.95 and $41.09 \mathrm{mg} / 100 \mathrm{gF}$.W.) and total flavonoids (3.23 and $3.14 \mathrm{mgCE} / \mathrm{g} \mathrm{D.W}$.) with yeast extract foliar application at 15 and $20 \%$, respectively. The highest total indoles leaves content $(60.18 \mathrm{mg} / 100 \mathrm{gF}$.W.) was obtained with foliar application $(15 \%)$ of dry yeast extract. It can also noticed that foliar application of yeast extract more than 5\% (10, 15 and 20\%) resulted in highest values of total soluble phenols $(72.48,72.27$ and $73.46 \mathrm{mg} / \mathrm{g}$ D.W., respectively).

Concerning the concentration of total soluble sugars, the best values of total sugar content and beneficial effect on carbohydrate accumulation in leaves of field bean were observed with yeast extract (Mady, 2009). For indoles, similar results were found when the maximum values in auxins were obtained with foliar application of yeast extract at $5 \mathrm{ml} / \mathrm{L}$ combined with boron at 50 ppm (Abou EL-Yazied and Mady, 2012).

As for phenolic compounds content, Yeast extract augments the enzyme activities of phenylpropanoid metabolism which leads to phenolic compounds (Ramachandra and Ravishankar, 2002).

The important roles of plant phenolics materialize in protection against biotic and abiotic stressors. They exhibit a wide range of biological activities including antibacterial, antiinflammatory, antiallergic, hepatoprotective, antithrombotic, antiviral, anticarcinogenic and vasodilatory (Soobrattee et al., 2005). Because of the pharmaceutical and economical values of phenolics, it is essential to recognize under which conditions they are synthesized. Ozgur and Sule (2009) observed that, cultures of Astragalus chrysochlorus treated with yeast extract inhibited the growth and coupled with coloring, the cells turned to claret-red. It was thought that the substances which are responsible for claretred color, may correspond phenolic compounds that account for pink, red, orange, scarlet, purple colors. Gang et al. (2012) studied the effects of Yeast polysaccharide (YPS) on the growth and flavonoids accumulation of Fagopyrum tataricum sprout cultures, which were dependent on both YPS concentration and its treatment period. The results provide further evidence for the elicitor activity the yeast polysaccharide (YPS) in stimulating the stress responses and secondary metabolism of Fagopyrum tataricum sprout cultures.

\section{CONCLUSION}

Applying of dry yeast extract positively affected most of studied growth characters, i.e. plants height, stem and root fresh and dry weights as well as pigments content and NPK (\%) of Neem plants. Moreover, total soluble sugars, indoles, phenols and flavonoids contents increased by application of dry yeast extract.

\section{ACKNOWLEDGEMENTS}

The authors are thankful to National Research CentreGiza- Egypt for funding this research.

\section{REFERENCES}

Abbas S. M. The influence of biostimulants on the growth and on the biochemical composition of Vicia faba CV. Giza 3 beans. Romanian Biotechnological Letters, 2013; 18 (2):8061-8068.

Abou El-Yazied A., Mady M.A. Effect of naphthalene acetic acid and yeast extract application on growth and productivity of tomato (Lycopersicon esculentum Mill.) plants. Research J of Agric and Bio Sci, 2011; 7(2): 271-281.

Abou EL-Yazied A., Mady M.A. Effect of boron and yeast extract foliar application on growth, pod setting and both green pod and seed yield of broad bean (Vicia faba L). J of App Sci Res, 2012; 8(2): 1240-1251.

Adom K.K., Sorrells M.E., Liu, R.H. Phytochemicals and antioxidant activity of milled fractions of different wheat varieties. J. Agric. Food Chem. 2005; 53: 2297-2306.

A.O.A.C., 1985. Official methods of analysis of the Association of Agriculture Chemists, $13^{\text {th }}$ Ed., Benjamin franklin station, Washington, DC, B.O. Box 450.

Dinkha R.F., Al-Khazragji T.O. 1990. Nutrition and fungus function science, University of Salahaddin, Ministry ofHigh Education, Iraq. (In Arabic).

Dubois M., Smith F., Gilles K.A., Hamitton J.K, Rebers P.A. Colorimetric method for determination of sugars and related substances. Anal. Chem., 1966; 28: 350-356.

El- Desouky S.A., Wans A. L., Khedr. Z. M. Utlization of some natural plant extracts (of garlic and yeast) as seed - soaked materials to squash (Cucurbatia pepo L). I- Effect on growth, sex expression and fruit yield and quality. J. Agric. Sci. Moshtohor, Zagazig. Univ., 1998; 35 (2): 839-854.

EL-Ghamriny E.A, Arisha, H.M.H., Nour K.A. Studies in tomato flowering, fruit set, yield and quality in summer season, I. Spraying with thiamine, ascorbic acid and yeast, Zagazig. J. Agric. Res., 1999; 26: 1345-1364.

El-Sherbeny S. E., Khalil M., Hussepn M.S. Growth and productivity of rue (Ruts graveolens) under different foliar fertilizers application. J. Appli. Sci. Res, 2007; 3 (5): 399-407.

Gang Z., Jianglin Z., Lianxin P., Liang Z., Jingbo W., Lingyun Z., Dabing X. Effects of Yeast Polysaccharide on growth and flavonoid accumulation in Fagopyrum tataricum sprout cultures. Molecules, 2012; 17: 11335-11345.

Hanafy M.S., Saadawy F.M., Milad S.M.N., Ali R.M. Effect of some natural extracts on growth and chemical constituents of Schefflera arboricola plants. J. of Horticultural Science \& Ornamental Plants, 2012; 4 (1): 26-33.

Homme P.M., Gonzalez B. , Billard J. Carbohydrate content, frutane and sucrose enzyme activities in roots, stubble and leaves of rye grass (Lolium perenne L.) as affected by sources/link modification after cutting. J Plant Physiol., 1992; 140:282-291.

Horneck D. A., Hanson D. 1998. Determination of potassium and sodium by flame Emission spectrophotometry. In hand book of reference methods for plant analysis, e.d Kolra, Y. P. (e.d). 153-155.

Horneck, D. A., Miller R. O. (1998). Determination of total nitrogen in plant tissue. In hand book of reference methods for plant analysis, e.d Kolra,Y.P.(e.d). 73.

Larsen, P., Harbo A., Siklungsan T. Asheim C. On the biosynthesis of some indole compounds in Acetobater xylinum. Physiol. Plant., 1962; 15: 552-565.

Mady M. A., Effect of foliar application with yeast extract and zink on fruit setting Faba bean (Vicia faba L). J Biol Chem Environ Sci, 2009; 4(2): 109-127.

Mahmoued T. R. 2001. Botanical studies on the growth and germination of mahnolia (Magnolia grandiflora L.) plants. M. Sci. Thesis. Fac. of Agric. Moshtohor, Zagazig Univ., Egypt.

Olaiya C.O. Presowing bioregulator seed treatments increase the seedling growth and yield oftomato (Lycopersicon esculentum). J Plant Growth Regul.2010; 29: 349-356. 
Ozgur C., Sule A. Defensive and secondary metabolism in Astragalus chrysochlorus cell cultures, in response to yeast extract stressor. J. Environ. Biol. 2009; 30(1), 51-55.

Premananda D. In Vitro somatic embryogenesis in some oil yielding tropical tree species. American J of Plant Sci, 2011; (2): 217-222.

Radwanski S.A. Neem Tree. 1. Commercial potential, characteristics and distribution. World Crops, 1977; 29: 62-63.

Ramachandra RS, Ravishankar GA. Plant cell cultures: chemical factoriesof secondary metabolites. Biotechnol. Adv.2002; 20:101-153.

Sandell R. 1950. Colorimetric determination of traces of metal 2nd Ed. Inter since. Pub. Inc. New. York.

Sarhan A.T., Sharif F.M. 1988 Fungus Physiology, Dar-ALkutub Publication, Mosul Univ. Iraq. (In Arabic).

Saric M.R., Kastrori-Cupina T., Gergis I. Chlorophyll determination Univ. Unoven Sadu-Prakitikum is Kiziologize BilikaBeagrad, Haucua Anjiga., 1967; pp: 215.

Snedecor G.W., Cochran G. W. 1980. Statistical Methods. 7th Ed. The Iowa State Univ. press Iowa, Ames, USA.
Soobrattee, M.A., V.S. Neergheen, A. Luximon-Rammaa, O.I Aruomab and T. Bahorun: Phenolics as potential antioxidant therapeutic agents: Mechanism and actions. Mutat. Res. 2005; 579: 200-213.

Wanas A. L. Resonance of faba bean (Vicia faba L.) plants to seed soaking application with natural yeast and carrot extracts. Annals. Agric. Sci. Moshtohor, 2002; 40 (1): 259-278.

Wanas A. L.Trails for improving growth and productivity of tomato plants grown in winter. Annals. Agric. Sci. Moshtohor, 2006; 44(3):466-471.

\section{How to cite this article:}

Taha LS, Ibrahim SMM, Aziz NGA. Vegetative growth, chemical composition, and flavonoids content of Azadirachta indica plants as affected by application of yeast natural extract. J App Pharm Sci, 2016; 6 (04): 093-097. 